\title{
The interagency guidelines on mental health and psychosocial support in emergency settings: implications for social work
}

\author{
Martha Bragin Ph.D. MSW \\ Associate Professor and Chairperson. Global Social Work and Practice with Immigrants and Refugees. Hunter College School of \\ Social Work. City University of New York, marthabragin@att.net
}

\begin{abstract}
The Interagency Standing Committee (IASC) launched a set of guidelines on mental health and psychosocial support in emergency settings in 2007. Since Social Work is the profession most often called upon to provide emergency services in countries where it is established, it is important that social workers are aware of the guidelines, understand their implications, and participate in this review at all levels. In the absence of guidelines as to how community resilience should be supported, humanitarian actors have sometimes been the cause of and not the solution to, psychosocial distress. The guidelines attempt to address these issues. But to be successful they must be understood and implemented by professional social workers in partnership with indigenous community members and their representatives, who are in the best position to evaluate their quality and effectiveness. This presents a new challenge and opportunity for the profession.

Resumen

En el año 2007, el Interagency Standing Committee (IASC), elaboró un conjunto de directrices sobre salud mental y apoyo psicosocial en contextos de emergencia. En tanto Trabajo Social es la profesión con mayor frecuencia requerida para proveer servicios de emergencia en los paises en que está establecido, es importante que los/as trabajadores sociales conozcan estas directrices, comprendan sus implicancias y participen en su revisión en todos los niveles. En ausencia de estas directrices, referidas a la manera en que debiera ser apoyada la resiliencia comunitaria, los actores humanitarios han sido en ocasiones la causa y no la solución del sufrimiento psicosocial. Las directrices apuntan a dar respuesta a estos temas. Pero para ser exitosas, ellas deben ser comprendidas e implementadas por las/os trabajadores sociales en conjunto con los miembros de las comunidades y sus representantes, quienes están en la mejor posición para evaluar su calidad y efectividad. Esto presenta un nuevo desafí y una oportunidad para la profesión.
\end{abstract}

\section{Introduction}

The twenty-first century began with a series of large scale disasters, both natural and man-made, devastating communities around the globe. Nowadays, emergencies are widely considered to be accompanied by social and psychological suffering for individuals, families and communities (van Ommeren and Wessells 2007). Of particular concern for social work is the way in which this suffering disproportionately affects poor and marginalized populations (Mathbor, 2007, Rosenfeld, Caye, Ayalon, and Lahad, 2005). Natural disasters are not natural alone. Whether they begin in nature or by human error in resource management, or through war and community violence, they affect commu- nities differently depending on the quality of the infrastructure, the quality and proximity of emergency services, and the ways in which authorities respond to community needs and organizational representatives.

With the development of humanitarian coordination, as well as the ability of the media to carry information about events around the globe, large scale humanitarian efforts have been mounted in both global north and south. In some of these situations, care for the mental health and psychosocial wellbeing of affected families and communities was well integrated in the overall disaster response, particularly in those instances in which established local and national social welfare agencies were able 
to take the lead. These interventions proved to be quite effective (Kasi, Bhadra and Dryer, 2007; Javadian, 2007).

However, in many situations, the care itself, and the relief arrangements thereafter, caused more psychological and social suffering than they addressed, especially among poor and marginalized populations (Kulkarni, et. al., 2008; IASC, 2007). This ranged from failure to help family members to stay together and find one another, leading to grief and despair, to poor information regarding the distribution of food and water -causing unnecessary confusion and social violence- to housing and sanitary arrangements that left many people -particularly women and children- vulnerable to attack and exploitation. Being in danger, not knowing where your family members are, and being unsure as to how your family will obtain access to the necessities of life can have profound effects on psychological wellbeing (Jones, 2008; van Ommeren and Wessells 2007).

In other situations, despite a lead focus on mental health by psychiatrists and psychologists, the needs of the seriously and persistently mentally ill were not taken into account, leaving them marginalized and vulnerable (Jones, 2008). Without global standards to guide practice, unqualified though well-meaning outsiders were able to swoop down and provide untested types of mental health and psychosocial care that did more harm than good; practices which people in distress, and their overburdened governments had little capacity to prohibit (van Ommeren, Saxena and Saraceno, 2005). In Sri Lanka in 2005, the onslaught of unqualified "helpers" was sometimes referred to as a "second tsunami" (Wickramage, 2006).

In other instances, in an attempt to provide a professional response, western psychology and psychiatry took the lead, with focused approaches on individual mental health that ignored the broader social and cultural domain, and often marginalized indigenous, culturally competent and holistic practices in favor of equally untested ones from the global north. Later, follow up research indicated that some of these practices, such as critical incident debriefing, were ineffective at best and harmful at worst in preventing adverse psychological reactions and long term readjustment (Hobfoll et al., 2007). Further, they did nothing to address the plight of the mentally ill, and had a debilitating and marginalizing effect on local systems of care (van Ommeren and Wessells, 2007).

\section{A new set of guidelines}

In an attempt to address these issues, a set of guidelines on mental health and psychosocial support in emergency settings was launched by the Interagency Standing Committee (IASC) in 2007. The Inter Agency Standing Committee that issued the guidelines, is a body established in response to General Assembly resolution 46/182 mandated to coordinate humanitarian action in emergencies, as well as to establish and advocate for best practice in humanitarian assistance (van Ommeren and Wessells 2007). Members include United Nations agencies, the Federation of Red Cross/Red Crescent Societies, the International Committee of the Red Cross, and the consortia of international and national NGOs (UNOCHA, 1999). The guidelines place culturally competent social service delivery, community ownership of decision making, participatory processes and human rights at the center of their focus. The guidelines also stress an integrated approach in which psychological and social wellbeing are addressed as part of the overall relief and recovery effort. These have long been the principles that professional social work has advocated (Bourassa, 2009; Rosenfeld, Caye, Ayalon, and Lahad, 2005). The guidelines are currently undergoing a process of "roll out" and review in the field. The purpose of this paper is to describe the guidelines, give examples of their practical application, and discuss their implications for the social work profession, in order to facilitate social work engagement in this dialogue.

\section{Some definitions}

Just as social work has common definitions that govern its work, so does the humanitarian community. In order to support social work engagement, it's important to insure that we all share a common vocabulary. The following definitions are the ones used in the IASC guidelines.

\section{Disaster}

Disaster is a serious disruption of the functioning of a community or a society involving widespread human, material, economic or environmental losses and impacts, which exceeds the ability of the affected community or society to cope using its own resources. A disaster is a function of the risk process. It results from the combination of hazards, conditions of vulnerability and insufficient capacity or measures to reduce the potential negative consequences of risk (UNISDR, 2009). 


\section{Coping capacity}

The means by which people or organizations use available resources and abilities to face adverse consequences that could lead to a disaster. In general, this involves managing resources, both in normal times as well as during crises or adverse conditions. The strengthening of coping capacities usually builds resilience to withstand the effects of natural and human-induced hazards (UNISDR, 2009).

\section{Resilience}

Resilience is the capacity to survive and thrive despite exposure to severe external stressors. Resilience is not magic. It is the result of the presence of protective factors that can counter balance risk (Würzer and Bragin, 2009).

\section{Psychosocial}

The term psychosocial was coined by the international relief and development community to define approaches informed by the ecological or bio-psycho-social perspective. It is the name given to the bio-psycho-social approach central to social work theory and practice (Bragin and Garcia, 2009). The prefix "psycho" refers to the psychological dimension of the individual, and has to do with the inner world of thoughts, feelings, desires, beliefs, values, cognition and ways in which people perceive themselves and others. The suffix social refers to the relationships and environment of the individual. It includes the material world as well as the social and cultural context in which people live, ranging from the network of their relationships, to cultural manifestations, to the community, on to the state. It is also used to refer to the socio-economic resources and material conditions of life. The term psycho-social is used to explain the way that these aspects of the person are inseparable, with each continuously influencing the other so that it is impossible to tease them apart (Duncan and Arntson, 2004).

\section{Psychosocial supports}

Psychosocial supports are social interventions intended to affect the psychological wellbeing as well as the social situation of the participants. Psychosocial supports are designed to improve psychosocial wellbeing through reducing risk factors and increasing protective factors, thus restoring resilience (Würzer and Bragin, 2009).

\section{Mental health}

Mental Health refers to a broad array of activities directly or indirectly related to the mental wellbeing component included in the Word Health Organization's definition of health: "A state of complete physical, mental and social well-being, and not merely the absence of disease". It is related to the promotion of well-being, the prevention of mental disorders, and the treatment and rehabilitation of people affected by mental disorders (WHO, 2010).

\section{Mental health treatment}

The guidelines differentiate mental health treatment from psychosocial supports, by referring to the psychological treatment of people with mental disorders, either pre-existing conditions or those induced by the disaster or the relief arrangements that follow, as mental health care (van Ommeren and Wessells, 2007). Thus the domains of the psychiatric and psychology communities are clearly and specifically delineated in the guidelines as separate and distinct from psychosocial and social work interventions.

\section{The PTSD controversy: treating victims or mobilizing community actors in the post-disaster context?}

In 1980, the diagnosis of Post Traumatic Stress Disorder (PTSD) entered the psychiatric nomenclature (van der Kolk, et. al, 1996). Based on studies of the experience of veterans in the United States, the new diagnosis allowed those veterans affected by their experience to receive needed benefits and care (Honwana, 1998). In the following years other political movements in the Unites States and Europe took up this diagnosis in order to clarify that social harm could have serious psychological effects and biological effects which could affect the life experience and worldview of survivors over time (van der Kolk, et al 1996). By medicalizing the effects of suffering, this diagnosis insured that victims would not be blamed for any sequelae they might manifest and that they could receive compassionate clinical care when needed (Bragin, 2010). PTSD treatments provide a mental health, as opposed to a psychosocial approach, to restoring wellbeing to people facing adversity. However in many parts of the world, this new diagnosis was treated with dismay. In Chile, members of ILAS, the Latin American Institute of Mental Health and Human Rights, were among the first to point out that the reactions to social problems cannot be seen as a disorder, but as the normal response to abnormal circumstances (Becker,1995). Further, ILAS noted that reducing 
the effects of massive loss and human rights abuse to a diagnosis could have the effect of trivializing and normalizing suffering, making it common place instead of a horror to be fought against (Becker, 1995, 2003). Others pointed out that where the entire society is struggling with a socially caused form of suffering, the pathology cannot be said to be living within the sufferer alone (Lira, 1995). They placed particular emphasis on the role of human rights violations, in the nature of the emotional sequelae of survivors. However, the same could be said to be true of survivors of earthquakes and other natural disasters.

Studies from sub-Saharan Africa, noted that the individual experience cannot be separated from its social and cultural meaning. Authors demonstrated that western based treatments were ineffective when delivered out of this context, and that culturally consonant and indigenous methods were often highly successful (Barton and Mutiti, 1998; Honwana, 1999). Clinicians from Asia described the effects of psychosocial care that is unrelated to cultural meaning as varying from amusing to dangerous to survivors of the Asian tsunami (Wickramage,2006). Others have pointed out that even the symptoms that people experience differ depending on their context, so that requiring specific "symptoms" to manifest in order to register suffering can leave those who need appropriate care outside of its range (Galappatti, 2004; Boothby, Strang, Wessells, 2006). Lira (1995), from Chile, was among the first to point out that one of the most important characteristics of disasters is that they occur in the public sphere. No matter how individualized a society, disasters happen to all of its members together. Therefore psychosocial interventions are needed to work with whole communities together and allow for the commonality of experience. The very fact of acknowledging the shared nature of the experience can help to break down fear and isolation, in order to support a sense of capacity, continuity and hope for the future (Becker, 2003; Lira, 1995; Honwana, 1998).

Many experts worried about the technical merits of a medical symptom-reduction approach to solving problems with serious long term causes. Psychological symptoms are defenses, armor, which the mind uses to keep something very painful away. Taking away a symptom then, does not solve the problem. It is better to solve the problem first and allow the symptom to go away. That is why community based psychosocial programs are preferable in many ways to treatment aimed at symptom reduction (Becker, Lira, Castillo, Gómez, and Kovalskys, 1990).

\section{A new consensus}

Recent studies have indicated that unlike survivors of rape, torture and imprisonment, the majority of people affected by disaster or mass violence, while changed in many ways, appear to be able to endure their experiences and even to find a measure of meaning and happiness in life, following their ordeal, with only about 5 to 6 percent, suffering from severe stress reactions (van Ommeren, Saxena, and Saraceno, 2005). However, wellbeing and recovery are predicated on the ways in which attention to life's necessities and to human connection are attended to, a principle well-known in social work (Bourassa, 2009; Bragin, 2011).

This is in line with the findings of Hobfoll et al (2007) in a consensus document on five empirically supported intervention principles in the immediate and early midterm stages of disaster. These consist of promoting: 1) a sense of safety, 2) calming, 3) sense of self and community efficacy, 4) connectedness and 5) hope (Hobfoll, 2007: 284). Not surprisingly, these principles amount to promoting the factors that mitigate psychosocial risk and support resilience (Unger, 2005).

Therefore, a simultaneous, multi-layered approach to the provision of services is necessary; one that targets every aspect of bio-psycho-social wellbeing, and not simply the prevention and response to individual psychological trauma (van Ommeren and Wessells, 2007).

\section{Overview of the guidelines}

The purpose of the guidelines is to enable humanitarian workers and community members to plan, establish and coordinate responses to protect and improve people's mental health and psychosocial wellbeing in the midst of emergencies, in accordance with the findings of contemporary research. They focus on the minimum response needed to insure people's immediate wellbeing but also try to point the way toward both prevention and ongoing comprehensive efforts (IASC 2007).

The guidelines were developed by an international team working over two years, consulting and amending them through a process of local consultation and feedback. Continuous feedback is needed to insure that they are an effective ethical and culturally competent tool. At the heart of the guidelines are 6 core principles, and 25 action sheets that illustrate how the principles can be operationalized during emergencies and after. 


\section{- Human rights and equity}

Human rights, especially those of vulnerable and marginalized persons must be attended to even in an emergency. Attention must be paid to marginalized and vulnerable persons. Their inclusion can support their mental health and psychosocial wellbeing.

\section{- Participation}

With self efficacy as a basic tenet of wellbeing, and the need to know the needs, resources and normative ways of coping with distress, it is vital that all members of the community who are able and willing to do so are included in early needs and resource assessments, as well in reconstruction efforts.

\section{- Do no harm}

Work on mental health and psychosocial support has the potential to cause harm because it deals with highly sensitive issues (IASC, 2007). Use of inappropriate, unproven, or coercive means can be dangerous. Therefore it is vital that providers maintain strict ethical and clinical standards, are updated on current thinking regarding best practice and be willing to accept evaluation and scrutiny by community members. Awareness of vulnerable and marginalized groups and the danger of human rights violations is also critical as measures intended to be helpful can lead to danger for some members of the population.

\section{- Building on existing resources and capacities}

By building on available resources and supporting the capacity of existing duty bearers, strengthening local organizations and supporting them, even disasters can present opportunities to strengthen existing coping mechanisms and prepare the way for the future.

\section{- Integrated support systems}

Creating specialized care systems that target only specific populations such as rape victims or those with a specific diagnosis can compromise service users and stigmatize some groups. In other instances these privilege some experiences and symptom clusters, creating "epidemics" caused by desperate people trying to suffer "correctly" in order to get what they need.

\section{- Multi-layered supports}

In order to fulfil these conditions effectively, the guidelines call for a multilayered approach as described in the pyramid below. Each level of service is necessary and all levels should be provided simultaneously, as best as possible.

\section{How Multi-Layered supports are operationalized: the key to implementation of the guidelines}

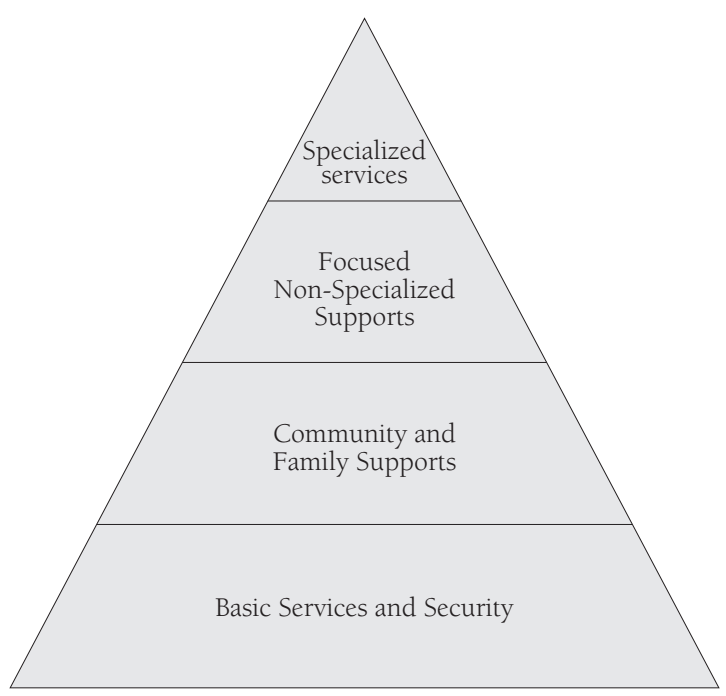

i. Basic services and security. These are the supports needed by the entire population and must be provided to all survivors immediately. They represent the ways in which information food, shelter, water and sanitation are provided to the population.

ii. Community and family supports. These supports are group oriented and sub-clinical. They involve many members of the community. Often they are designed by community members and supports are brought to bear as requested.

iii. Focused, non-specialized supports. The third layer represents the supports necessary for the still smaller number of people who additionally require focused individual, family or group interventions by trained and supervised workers. This layer also includes psychological first aid.

iv. Specialized services. The top layer of the pyramid is for those members of the community who are either mentally ill and need access to medication and other care continued, and those who are having a severe reaction to the events and require professional treatment.

\section{The role of social work in providing and coordinating a multi-layered approach to service delivery}

A natural disaster has struck. You don't know where your family members are, where you can go to be safe, 
where you can find a bathroom (and your 5 year old infant needs one badly), youdon't know where you will sleep tonight and how long it will be until you are safe. You certainly don't know what will happen next.

You hear from some community leaders that there is transport to safety and that food and water are being distributed and they direct you to the proper place. But when you get there authorities greet you with loaded guns and send you back into flooded area with your 5 year old infant.

Denied safe passage at every turn, with flood waters rising around you, and terrified for your children's lives, you put your baby in the arms of strangers on a bus to safety. You try to do the same with the five year old, but she shrieks and clings to you, so you hang on for dear life and hope for the best. No one takes the trouble to record the information for you and tell you how to find your baby again when you are safe.

You find your spouse at the crowded chaotic shelter, where they say the bathrooms are unsafe, and the little one is crying. Rumors are flying and you don't know what to believe. Are their looters? Are dangerous people on the prowl? Some of the scariest may be true...the marginalized community leaders are not able to help, now that the men with the guns have appeared...

Meanwhile your spouse can't forgive you for putting the baby on the bus, you are mad with worry, and meanwhile you have lost everything that you ever owned. As you struggle to locate your baby, support your child, search for grandma among the unmarked dead you must face the recrimination of family members as well as try to find a home and means to make a living. You begin to despair and think that you can't go on... (Bragin, 2010).

In this vignette, from Hurricane Katrina in the United States of America, one can see how human rights violations, failure to consult with and empower local leaders, as well as lack of clear and accurate information, combined to amplify the problems experience by flood affected families. The fact that these errors occurred in one of the wealthiest and most-developed countries in the world, indicate that it is not a question of resources, but failure of application of best practice standards that created much of the difficulty (Bourassa, 2009; Kulkarni, et. al, 2008; Pyles 2007)

Therefore the guidelines provide minimum standards for actions that can be taken during an emergency. Some are actions that social workers can take in advance, in order to be prepared.

\subsection{Basic services and security: what actions can support psychosocial wellbeing}

1.1.1 Provide clear, accurate and coordinated information to the population

People in the midst of disaster need the following information:

- What is known and not known about the nature of the disaster

- Where they can go to be safe

- Where they CANNOT go to be safe

- Where services are being provided

- Who can get the services

- How to register to locate missing family members

Insure that information on these issues is disseminated clearly, consistently, regularly and in all locally spoken languages.

\subsubsection{Develop coordinating structures from the local to larger community level}

By getting information from all of those who can help and insuring that no one is working alone, coordinated efforts can insure maximum inclusion. Such coordination will make the next steps possible. Participate in the immediate development of a central coordinating body, and within it a psychosocial working group that can help insure that everyone knows who is doing what where. This prevents clustering of services targeted at the "easiest to reach" with others left with nothing.

\subsubsection{Involve community members in defining their own wellbeing and that of their chil- dren, through community participatory monitoring and evaluation}

A coordinated participatory assessment process should begin immediately.

Community members should identify their own coping mechanisms:

- What is in place? What is missing? What more/ new is needed?

- Which usual or traditional practices inhibited access to vulnerable people

- Who needs to be involved in creating change where change is needed?

Community based monitoring and evaluation of clinical interventions can begin early as well, forming part of the assessment. Community members can also be asked to target specific vulnerable groups and have their success in part measured by their capacity to include them and get that information 
to those distributing relief (This entire section from IASC 2007 Action sheet $2.1-2.2)^{1}$.

\subsubsection{Prevent family separations}

The worst thing that can happen to anyone in a disaster is to lose the people that they love. In the case of children, especially those too young to speak for themselves, the loss of parents and siblings has important developmental implications (Freud and Burlingame, 1943; Duncan and Arntson, 2004; Jones 2008). The guidelines are clear that before thinking about caring for separated children and those who have become orphans it is critical to prevent separations in the first instance.

In order to accomplish this, social workers can build awareness of the importance of tagging children under five amongst families, teachers, first responders and youth groups. Tagging small children is a simple activity of critical importance that can help youth to fight feelings of helplessness and fear. Prior to the emergency family members, young people who are eager to help, and first responders can all be equipped with materials. During the emergency they can engage in tagging young children under five, the elderly, disabled, and people in institutions to prevent family separations.

\subsubsection{Identify the dead before they are buried and inform families as soon as possible}

One of the greatest sources of psychosocial distress is not knowing whether a loved one is dead or alive. It makes grief and mourning difficult and renders "getting on with life" almost impossible, and for children, it is critical in making plans for their future. Therefore, identification of the dead and notification of the living are the precursors of the restoration of wellbeing.

Fortunately, when healthy people die in disaster or terror attack, the bodies can be preserved a day or two prior to burial so that identification and registration can be made and if possible, family members can be found and notified. There is no health related need for immediate mass burial as there is when people die of disease (Wisner and Adams, 2002).

Social workers can coordinate with health workers to insure that bodies are identified before they are buried or cremated and whenever possible surviving relatives are able to dispose of them in their own way. This can be done through participation in coordination meetings as described above.

\subsubsection{Train those who distribute emergency ser- vices, i.e. food and nutritional support, shelter, water and sanitation}

These basic services are often provided by people trained in emergency management, first responders or the military. If we want to insure the participation and collaboration necessary to provide these basics in a way that supports wellbeing, promotes safety and ensures equity, the emergency responders who do this distribution need training in the principles of supporting psychosocial wellbeing in the midst of emergencies, through participation, collaboration and empowerment.

\subsubsection{Ensure the protection of marginalized groups}

Very often in an emergency those who are "normally" disenfranchised in a society remain invisible until their problems reach acute proportions. For example, after the events of 9/11/01 in the US, the families of the undocumented workers of color who were killed during the disaster did not receive the same level of support that others did, until advocates sought them out and worked on their behalf. Such problems can occur in any society. Learning about structures of power and historic discrimination are critical parts of any assessment so that even when cultural traditions are being honored and maintained, those that support discrimination and injury are not. In India and China, social workers now routinely map disaster prone communities prior to any new disaster so that this process can be speeded up when the emergency arrives (Doostgharin, 2009; Sim, 2009).

Case Example: Supplementing food distribution in Northern Japan.

Following the devastating triple disaster of a powerful earthquake, 7 of the highest tsunami waves on record, and the resulting leak of radiation from a nuclear power-plant, the coastal region of northern Japan was left in shambles. 12,554 people were known dead and an additional 15,077 continued missing one month after the disaster (Japan Platform, 2011). Good practice was shown by the Self Defense Forces when they tagged and identified family and community members and organized them in shelters together, distributing food and shelter items (diapers, sanitary products), rapidly and transparently. They also stood guard at every shelter, insuring safety and an orderly process that allowed for everyone to receive necessities in peace. Bulletin boards, run by

1 The entire participatory assessment methodology is available at this website: http://www.interventionjournal.com/downloads/31pdf/03_24\%20Bragin\%20.pd 
traditional community leaders, posted descriptions of the missing.

However, the communities survived mostly by means of the maritime economy, and nearly everyone had lost everything that they owned. The food that they received were army rations alone, nutritionally adequate, but as cold and impersonal as the shelters themselves.

A humanitarian agency that normally sent japanese aid work professionals overseas to help others, rushed to the scene to provide needed supplies beyond the necessities. They determined that people's wellbeing would be enhanced by hot meals in the shelters. Hiring a cook with experience in japanese spiritual traditions, and aided by volunteers, they began by providing two hot meals a day. They moved from simply providing the food, to being able to use it as a way to engage people in thinking about simple things that they could still enjoy. After receiving training in psychological first aid from the social workers on staff, the volunteers could not only feed the residents, but also hear them when they needed to talk. They could move from talking about the food, what they liked and didn't, to confiding in the volunteers. The residents slowly, were able to organize to order foods and prepare meals that they liked, and with that basis, think about their future. From this basis the residents were able to move from victims to program participants.

\subsection{Community and family supports}

Community and family supports are those that are normally available to help people through hard times. Some people in a disaster are just fine if the provision of services is transparent and if the conditions described above are met. Others will need some additional supports. Among the groups who are in need of specialized services are children, who experience disaster differently depending on age and stage of development.

\subsubsection{Child friendly spaces}

"Child Friendly Spaces" are an intervention that gives children a safe place to play, allowing parents to deal with the emergency situation. They engage community volunteers, especially adolescents and elders, in feeling useful by helping the children. It protects children from danger and begins to provide a sense of routine. If the space includes a time for mothers of small children to be with babies, they too can get support. Sometimes, adolescent clubs are also organized in child friendly spaces, where teens can start as volunteers working with youn- ger children, but later can begin to make sense of their experience by explaining it to younger children, and of finding ways to feel useful to others. Elders, who may wonder how they can pick up the pieces and start again find pleasure in organizing activities for children, telling stories can help them to maintain their own cognitive capacity by creating coherent narratives.

Case Example: Spaces for Children in Sri Lankal

Radha was a member of a local youth club for poor kids, run by an international social service organization in Sri Lanka. The club comprised young people who had been beneficiaries of social and economic support when they were small. They had a club house. It was a place that you could hang out and not be hassled.

When the tsunami struck, destroying everything in its way, these young people were already organized! Radha convinced the others not to just sit back but to do something. The teenagers got on their bicycles and road to the disaster area.

There was so much to do that they didn't know where to start! But the social welfare organization that had organized them had work for them to do; organize spaces where children can play.

Families were sheltering in crowded structures, and the rubble from the tsunami was dangerous. Children were fearful of the sea, but could not really find space for themselves on land. The young people were helped by social workers to find safe spots for kids to play, and organized them by age groups. Teachers among the survivors also were able to pitch in. The spaces were used by pre-schoolers during the day when children were at school, with support from elders, who might otherwise have been in despair. After school, part of the time was spent with teenagers providing safe space for younger children to play. Evenings found space for homework help and support.

Through guided play and drawings, children were helped to express their feelings. They were also able to learn that it was okay to try to have fun again. Routine was restored making life not seem to have desolved into chaos, and parents were able to organize around helping their children get through the crisis, giving them hope for the future. Finally, again, those elders who had lost so much, could be useful to others and with the little ones, begin to create a narrative that made sense of it all. 


\subsection{Focused, non-specialized supports}

This category of support refer to groups of people whose special situation require concern, but may not require clinical intervention, as the distress that they are experiencing are shared by the entire community. One example of such groups is those who have lost immediate family members. Not all members of these groups will require clinical interventions, but recognition of their losses as personal and the need to mourn according to their own personal beliefs, customs and traditions are critically important for this group.

\subsubsection{Learn about and where appropriate collabo- rate with local, indigenous and traditional health systems}

Traditions of healing may seem long ago and far away to city residents, yet as social workers we know that indigenous ideas of health and wellness are critical to our capacity to make meaning of extreme experiences. Traditions help us understand death and loss, in particular.

Case example: a Chinese community copes with loss

The fact that every single child was in school that day was a source of pride to this small ethnic minority community in Western China. Not so long ago, the rural schools were of poor quality, and did not continue past grade 4. Few students went further than an elementary education. The perceived complication of an ethnic minority language spoken at home, posed educational challenges. But by the day of the big earthquake, there were three schools in the nearby large town; elementary, middle and high school. No one kept children at home. There were several regional universities and technical schools to choose from. The school buildings were tall and well equipped, not some one story rural pre-fabricated affair that could be seen in rural schools in other countries. This hard-working ethnic minority felt that they had really "made it".

So parents sent the children to school happily the morning of the earthquake, but some had to argue and insist. Everyone of the schools in town collapsed, killing all of the students and teachers inside. People with young children lost their only child. Everyone had to wait for two days until the Army came with helicopters, rescuing the living, exhuming and helping to cremate the dead.

The community was devastated. There were no words. They thought that they were helping their children by insisting that they go to school, but they had sent them to their deaths. While care was needed for all community members, the parents who had lost their children required supports focused just on them. Supports that called upon their oldest and most valued traditions, and gave them space to heal slowly, over time.

Local social work teams, came discovered a local tradition that had survived a century of upheaval: traditional dance. The teams came to understand that weekly dancing was a way for the community to connect to their past, as they slowly began to rebuild their future. Each generation taught the dances to the next, and they practiced them together with their children week after week. Slowly, the social work team supported the parents to revive their dance troupe. At the first anniversary of their children's death, and the destruction of their community, the troupe danced for an international audience.

They wept, they remembered, but then they danced, with surviving children from the community (those too old or young to have been at school that day) dancing along.

The loss of a child is forever, and the grief may never go away. But those with guilt and pain and grief that they could not bear, drew strength from one another and began the slow process of healing (From Bragin, 2010. 387).

\subsection{Specialized services}

In an emergency, the mentally ill are often forgotten. Yet they are more likely to be confused and distressed by events than the rest of the population. It's important to ensure that at least one agency is taking charge of providing mental health services, and supporting both the primary health care and mental health systems to continue service delivery.

\subsubsection{Ensure continuity and integrity of care for the mentally ill}

Make sure that psychotropic drugs on which patients are dependent are available, even when records have been destroyed. Insure that psychiatrists and psychiatric nurses are deployed to serve the mentally ill and supported in their mission.

Where traditional treatments are the norm of care for this population, social workers can insure continuity through familiarizing the two groups of practitioners with one another and facilitating communication.

\subsubsection{Institutionalized mentally ill}

While the best care is community based, and provided through the primary care system, some mentally ill people are cared for in institutions. Prior to any emergency, mental patients can be is- 
sued identification tags so that they do not become lost in disasters. It is important to prepare staff for the eventuality of a disaster and assign specific persons to take responsibility during an emergency.

If social workers discover an institution that has been abandoned, their first task is to insure that residents obtain food, water and medicine quickly. The second task is to alert governmental duty bearers to the situation and to insure that a qualified agency is assigned to take responsibility for the care of the residents until systems of care are restored.

Case Example: Supporting the mentally ill in Haiti Following the devastating 2010 earthquake in Haiti, nearly all government buildings and all institutions were destroyed. There had been a mental hospital in the capital where many families sent mentally ill members. Some of the patients survived the earthquake, but did not have staff to care for them. Social workers eager to intervene supported the Ministry of Health to survey the needs of the surviving patients and nurses at the facility. They arranged for emergency staff to support them so that they could take breaks, but did not try to supplant the authorities, as they were sacrificing everything that they could to help those in need.

After identifying surviving patients and making sure that their whereabouts were known, and supporting the staff to get regular breaks as they re-organized the hospital's routine, they worked with the Ministry of Health to develop a long term plan for the facility. They organized volunteers from among local young people, and traditional healers to engage with the facility and to begin to think of ways that they could develop community care.

\subsubsection{People who require additional clinical care}

There will always be a small number of people who, despite psychosocial supports like those recommended here, are unable to tolerate the emotional stress of an emergency, and after some period of time require clinical care. The first line of defense is the inclusion of outpatient mental health services in repertoire of primary care providers. Social workers will often be called upon to provide this care in accessible and appropriate settings themselves providing such services after the emergency is over, to individuals groups or families. Among those most vulnerable in times of disaster are those who have suffered complicated grief, and those who are vulnerable due to a combination of family or personal history.

\section{Implications for the social work profession}

The IASC guidelines for Mental Health and Psychosocial Support in Emergency Settings are an international standard designed to insure that the psychosocial supports provided to needy population, meet the highest standards for quality,. The guidelines place social work skills and values such as participatory methodologies, inclusive and empowering responses, and culturally competent community based services at their centre. The guidelines are currently being rolled out, reviewed and modified through field tests and experience in emergency situations world wide. The social work profession should be participating actively in this process, critiquing the guidelines where they need improvement and promoting them where they do meet the standards of the profession. Social work as a profession, and not only social work practitioners as individuals should be at the table, finalizing the guidelines, and promoting their use. Already, social work plays a lead role in disasters in many of the countries where the profession is well established (Bragin and Garcia, 2009). Mathbor (2004) has argued that social work curricula must be expanded to include courses in disaster response, as is already happening in China, India and Bangladesh. Such social work programs should include the IASC guidelines in Mental Health and Psychosocial Support in Emergencies in their emergency management and disaster preparedness and relief curricula.

\section{References}

BARTON, T., \& MUTITI, A. (1998). Northern Uganda psycho-social needs assessment report. Kampala: UNICEF.

BECKER, D. (1995). The deficiency of the concept of posttraumatic stress disorder when dealing with victims of human rights violations. In R. Kleber, C. Figley, $\&$ B.Gersons (Eds.), Beyond trauma: Societal and cultural dynamics (pp. 99-114). New York and London: Plenum Press.

BECKER, D. (2003). Mental health and human rights: thinking about relatedness of individual and social processes. Paper presented at the International Conference "Towards a better future: building healthy communities." Belfast October 2003. Retrieved July 1, 2010:http://www.medicointernational.de/en/projects/ social/ps_becker_en.pdf

BECKER, D. AND WEYERMANN, B. (2006): Gender, conflict transformation $\mathcal{E}$ the psychosocial approach - Toolkit. Swiss Agency for Development and Cooperation. Retrieved 12/19/08 from: www.deza.admin.ch 
BECKER, D., LIRA, E., CASTILlO, M.I.,.GÓMEZ, E, KOVALSKAYA, J. (1990). Therapy with victims of political repression in Chile: The challenge of social reparations. Journal of Social Issues. 46 (3) 133-149.

BOOTHBY, N., STRANG, A., WESSELLS, M. (2006). A world turned upside down: social ecologies of children and war. Bloomfield, CT: Kumarian Press.

BOURASSA, J. (2009). Psychosocial interventions and mass populations: A social work perspective. International social work. 52 (6) 743-755.

BOYDEN, J. AND MANN, G. (2005). Children's risk, resilience and coping in extreme situations. In M. Ungar (Ed.) Handbook for working with children and youth: Pathways to resilience across cultures and contexts. (pp. 3 - 25). Thousand Oaks: Sage.

BRAGIN M. (2005): Psychosocial CARE in Emergencies: A Mini-Guide for Practitioners. Vienna: Care Austria.

BRAGIN, M. (2005a) The Community Participatory Evaluation Tool for Psychosocial Programs: a guide to implementation. Intervention: International Journal of Mental Health, Psychosocial Work and Counseling in Areas of Armed Conflict 3(1) 3 - 24

BRAGIN, M. (2010). Clinical social work in situations of disaster and terrorism. In J. Brandell (Ed). Clinical social work practice. $2^{\text {nd }}$ Edition. New York and London: The Free Press.

BRAGIN, M., AND WÜRZER, J., (2009). Integrating the psychosocial dimension in women's empowerment programming: a guide for CARE country offices. Vienna: CARE Österreich.

BRAGIN, M. AND GARCIA, M. (2009). Competencies required to design and implement programs for children and adolescents affected by natural disaster and complex emergencies: Are these competencies those of international social work practice? Journal of Global Social Work Practice 2 (2).

DIAZ, L., MAMA, R. AND LOPEZ L. (2006). Making the social work profession an essential partner in international development. Washington DC: NASW Retrieved 09/08/09 http://www.socialworkers.org/practice/intl/ InternationalPartner.pdf

DOOSTGHARIN, T. (2009). Children affected by earthquakes and their immediate emotional needs. International Social Work. 52 (1): 96 - 106.

DUNCAN, J. AND ARNTSON L. (2004). Children in Crisis: Good Practices in Evaluating Psychosocial Programming. (p.16.) Washington, D.C.: International Psychosocial Evaluation Committee and the Save the Children Federation, Inc.

DRUCKER, D. (2003). Whither international social work? A reflection. International social work 46 (1) 5681.
FEDERICO, M., PICTON, C., MUNCY, S., ONGSIAPCO, L., SANTOS, C. AND HERNANDEZ, V. (2007). Building community following displacement due to armed conflict: a case study. International Social Work. 50 (2) 171-184.

GUO, W. AND TSUI, M. (2010). From resilience to resistance: A reconstruction of the strengths perspective in social work practice. International Social Work 53 (2) $233-245$.

HALPERN AND TRAMONTIN (2007). Disaster mental health: theory and practice. Belmont CA: Thompson Brooks-Cole.

HEALY, L. (1987). International agencies as social work settings: opportunity, capability, and commitment. Social Work 32 (5) 405-409.

HEALY, L. (2007). Universalism and cultural relativism in social work ethics. International Social Work. 50(11) 11-26.

HOBFOLL, S., WATSON, P., BELL C, BRYANT, R.,BRYMER, M., FRIEDMAN, M.J., FRIEDMAN, M., GERSONS, B., DE JONG, J., LAYNE, C., MAGUEN, S., NERIA, Y., NORWOOD, R., PYNOOS, R., REISSMAN, D., RUZEK, J. SHALEV, A., SOLOMON, Z., STEINBERG, A, AND URSANO, R. (2007). Five essential elements of immediate and mid-term mass trauma intervention: empirical evidence. Psychiatry: 70 (4) $228-315$.

HONWANA , A. (1999). Challenging western concepts in trauma and healing. Track Two: Culture and conflict. (8) 1 Retrieved 01/07/10 http://196.25.102.27/archive/ two/8_1/p30_collective_body.html

IASC (2007). Guidelines on mental health and psychosocial support in emergency settings. Geneva: Interagency Standing Committee. Available at: http://www.humanitarianinfo.org/iasc/mentalhealth_psychosocial_support

INTER-AGENCY WORKING GROUP ON UNACCOMPANIED AND SEPARATED CHILDREN. (2004). Inter Agency Guiding Principles on Unaccompanied and Separated Children. Geneva: International Committee of the Red Cross, Central Tracing Agency and Protection Division. Retrieved 01/07/10 from: http://www.unicef. org/violencestudy/pdf/IAG_UASCs.pdf

INTERNATIONAL ASSOCIATION OF SCHOOLS OF SOCIAL WORK AND INTERNATIONAL FEDERATION OF SOCIAL WORK (2004). Global standards for the education and training of the social work profession. Adelaide, Australia: Author Retrieved 09/09/09 http://www.ifsw.org/cm_data/GlobalSocialWorkStandards2005.pdf

INTERNATIONAL RESILIENCE PROJECT. (2006). Project Report: 2006. Halifax Nova Scotia, Dalhousie University: The International Resilience Project http://www. resilienceproject.org/index.cfm? fuseaction=text. \&str_ cmpID=221 
JAPAN PLATFORM (2011). Situation Report 8 April, 2011. Tokyo: Japan Platform and Janic.

JAVADIAN, R. (2007). Social work responses to earthquake disasters: a social work intervention in Bam, Iran. International Social Work. 50 (3) 334-346.

JONES, L. (2008). 'Responding to the needs of children in crisis', International Review of Psychiatry, 20:3, 291 303: DOI: 10.1080/09540260801996081 URL: http:// dx.doi.org/10.1080/09540260801996081

KASI, S., BHADRA, S., AND DRYER, A. (2007). A decade of disasters: Lessons from the Indian experience. Southern Medical Journal 100 (9) 929-931.

KULKARNI, S., BELL, H., BEAUSOLEIL, J., LEIN, L., ANGEL, R., MASON, J., (2008). When the floods of compassion are not enough: A nation's and a city's response to the evacuees fo Hurricane Katrina. Smith college studies in social work 78 (4) 399- 425.

LIRA, E. (1995). The development of treatment approaches for victims of human rights violations in Chile. In R. Kleber, C. Figley, \& B.Gersons (Eds.), Beyond trauma: Societal and cultural dynamics (pp. 99-114). New York and London: Plenum Press.

LYONS, K. (2006). Globalization and social work: international and social work implications. British Journal of Social Work, 36365 -380.

MATHBOR, G. (2007).Enhancement of community preparedness for natural disasters: The role of social work in building social capital for sustainable disaster relief and management. International Social Work, 50(3): 357-369

MILLER, M. (2003). Working in the midst of collective trauma and traumatic loss: Training as a collective process of support. Psychoanalytic Social Work, 10 (1): 7 - 25.

MYERS, D. AND WEE, D. (2004). Disaster mental health services: a primer for practitioners. New York: Brunner-Routledge.

PAWAR, M. (2008). Disaster preparedness/Management Agencies and Centers. Asia Pacific Journal of Social Work and Development. 18 (2).

PAWAR, M. (2008a). Editorial: Interventions in Disasters. Asia Pacific Journal of Social Work and Development. $18(2)$.

POWELL, F. AND GEOGHEGAN, M. (2005). Reclaiming civil society: the future of global social work? European Journal of Social Work. 8 (2) 129 - 144.

PYLES, L. (2007). Community organizing for postdisaster social development: Locating social work. International Social Work, 50 (3) pp 321-333.

RIVERA, M., PÉREZ-SALES, P., APARCANA, J.L., BAZÁN, M., GIANELLA, C., AND LOZANO, A. (2008). Community mobilization after an earthquake. Intervention: International Journal of Counselling, Mental Health and Psychosocial Support. 6 (3/4) 275 -283.
ROFF, S (2004). Non-governmental organizations: the strengths perspective at work. International Social Work. 47 (2) pp 202-212.

ROSENFELD, L. CAYE, J, AYALON, O., AND LAHAD, M. (2005). When their worlds fall apart: Helping children and families manage the effects of disasters. Washington: DC NASW Press

SIM, T. (2009). Social work capacity building and professional support in post disaster reconstruction. Paper presented at the Symposium on Sichuan Post-quake Recovery and Reconstruction. Chengdu People's Republic of China.

STEIN, H. (2006). Does mentalizing promote resilience? In J. Allen and P. Fonagy (Eds). Handbook of Mentalization Based Treatment.

UNGAR, M. (2005). Introduction: Resilience across cultures and contexts. M. Ungar (Ed.) Handbook for working with children and youth: Pathways to resilience across cultures and contexts. (pp. xv - xxxix). Thousand Oaks: Sage.

UNITED NATIONS INTERNATIONAL STRATEGY FOR DISASTER REDUCTION (UNISDR). (2007) International Strategy for Disaster Reduction: Global Platform. http://www.unisdr.org/index.php

UNITED NATIONS INTERNATIONAL STRATEGY FOR DISASTER REDUCATION (UNISDR). (2009). International strategy for disaster reduction: terminology. Retrieved on September 9, 2009: http://www. unisdr.org/eng/terminology/terminology-2009-eng. html

UNITED NATIONS OFFICE FOR THE COORDINATION OF HUMANITARIAN AFFAIRS (1999). OCHA orientation handbook on complex emergencies. United Nations. Retrieved May 30,2009 from http://www. reliefweb.int/library/documents/ocha_orientation_ handbook_on_.htm

VAN DER KOLK, B., MCFARLANE, A., \& WEISAETH, L. (Eds.). (1996). Traumatic stress: The effects of overwhelming experience on mind, body, and society. New York: Guilford Press.

VAN OMMEREN, M.\& WESSELLS, M. (2007). Interagency agreement on mental health and psychosocial support in emergency settings. Bulletin of the World Health Organization. 85 (11) 822.

VAN OMMERAN, M. SAXENA,S. AND SARACENO, B. (2005). Aid after disasters: Needs a long term public mental health perspective. British Medical Journal. 330 1160-1161 doi:10.1136/bmj.330.7501.1160

VAN SOEST, D. (1997). The global crisis of violence: common problems, universal causes, shared solutions. Washington DC: NASW press.

WICKRAMAGE, K. (2006). Sri Lanka's post-tsunami psychosocial playground: lessons for future psychosocial programming and interventions following disasters. 
Intervention: International Journal of Counselling, Mental Health and Psychosocial Support. 4 (2) 163-8.

WISNER, B. AND ADAMS, J. (2002). Mortuary service and the handling of the dead. Environmental health in emergencies and disasters: a practical guide. (pp.198202). Geneva: World Health Organization. Retrieved 1/6/05: http://www.who.int/water_sanitation_health/ hygiene/emergencies/emergencies2002/en/

XU, Q. (2006) Defining International Social Work: A Social Service agency perspective. International Social Work 49(6) 679-692.

YANAY, U., AND BENJAMIN, S. (2005). The role of social work in disasters. International Social Work. 48 (3) 263-276.

\section{List of acronyms}

IASC Inter Agency Standing Committee.

IASSW International Association of Schools of Social Work.

ICRC International Committee of the Red Cross

IFRC International Federation of Red Cross and Red Crescent Societies.

IRC International Rescue Committee.

UNHCR United Nations High Commissioner for Refugees.

UNICEF United Nations International Children's Emergency Fund.

UNISDR United Nations International Strategy for Disaster Reduction.

UNOCHA United Nations Office for the Coordination of Humanitarian Affairs. 